\title{
ANALISIS NILAI-NILAI KARAKTER ISLAM DALAM PEMBELAJARAN IPS DI MTS MAZRO'ILLAH LUBUKLINGGAU
}

\author{
Isbandiyah $^{1}$, Wati Ningsih ${ }^{2}$ \\ ${ }^{I}$ STKIP-PGRI Lubuklinggau, Lubuklinggau, Indonesia \\ E-mail: isbandiyah@stkippgri-lubuklinggau.ac.id \\ ${ }^{2}$ STKIP-PGRI Lubuklinggau, Lubuklinggau, Indonesia \\ E-mail:wsinta11@yahoo.com
}

\begin{abstract}
Abstrak. Penelitian ini bertujuan untuk mendeskripsikan nilai-nilai karakter Islam dalam pembelajaran IPS di MTs Mazro'illah Lubuklinggau. Jenis penelitian yang digunakan adalah penelitian kualitatif deskriptif. Adapun subjek dalam penelitian ini adalah siswa kelas IX. Teknik pengumpulan data yang digunakan adalah teknik koesioner. Hasil penelitian menunjukkan bahwa secara keseluruhan nilai-nilai karakter Islam sudah tertanam baik di dalam diri siswa, hal ini dapat dilihat dari hasil analisis menggunakan persentase sederhana, yaitu (1) nilai aqidah dengan jumlah persentase sebesar 91,67\%; (2) nilai ibadah dengan jumlah persentase yang diperoleh sebesar 87,5\%; dan (3) nilai akhlak dengan jumlah persentase yang diperoleh sebesar 95,7\%. Berdasarkan hasil penelitian tersebut, maka dapat disimpulkan bahwa nilai-nilai karakter Islam yang tertanam dengan baik secara berurutan yaitu nilai akhlak, nilai aqidah, dan nilai ibadah.
\end{abstract}

Kata kunci: nilai-nilai karakter Islam

\section{PENDAHULUAN}

Era globalisasi di Indonesia tentu membawa perubahan-perubahan yang berpengaruh bagi dunia pendidikan, baik pengaruh positif dan negatif. Untuk meminimalisir masuknya pengaruh negatif, perlu adanya suatu perubahan, yaitu menyesuaikan kurikulum IPS dengan perubahan yang terjadi secara global, agar peserta didik mampu memahami, manganalisis, merefleksikan berbagai fenomena yang terjadi secara global dan memfilter informasi sesuai dengan kebutuhan pendidikan.

Namun dewasa ini, pelaksanaan proses pembelajaran IPS masih mengalami problematika. Temuan dari beberapa penelitian yang ditulis oleh Soemantri yang dikutip oleh Gunawan (2016) menginsyaratkan bahwa pembelajaran IPS di sekolah selalu disajikan dalam bentuk faktual, konsep yang kering, guru hanya mengejar target pencapaian kurikulum, tidak mementingkan proses, karena itu pembelajaran IPS selalu menjenuhkan dan membosankan dan oleh peserta didik dianggap sebagai pelajaran kelas dua.

Selain itu, muncul juga permasalahan di kalangan peserta didik, yaitu menurunnya etika peserta didik, baik etika terhadap gurunya, maupun kepada sesama temannya. Menurut Lickona yang dikutip oleh Gunawan (2012) menyatakan bahwa ada 10 tanda jaman yang kini terjadi dan dapat membawa bangsa menuju jurang kehancuran, yaitu: (1) meningkatnya kekerasan di kalangan remaja; (2) penggunaan bahasa dan kata-kata yang buruk; (3) pengruh peer group yang kuat dalam tindakan kekerasan; (4) meningkatnya perilaku yang merusak diri seperti narkoba, sex bebas, dan alkolhol; (5) kaburnya pedoman moral baik dan buruk; (6) penurunan etos kerja; (7) rendahnya rasa hormat kepada orang tua dan guru; (8) rendahnya tanggungjawab baik sebagai individu dan warga negara; (9) ketidakjujuran yang telah membudaya; dan (10) adanya rasa saling curiga dan kebencian diantara sesama.

Fenomena-fenomena tersebut merupakan permasalahan yang terjadi sampai sekarang, dan dimungkinkan terjadi karena proses pembelajaran di kelas lebih menekankan pada aspek pengetahuan saja. Sementara kemajuan teknologi semakin berkembang, sehingga menyebabkan mudahnya peserta didik dalam mengakses segala informasi yang ada. Oleh karena itu, sebagai upaya untuk mengatasi problematika tersebut, agama diharapkan dapat memberikan perspektif baru dalam memecahkan permasalahan sosial yang dihadapi terkait dengan adanya kemajuan teknologi di era globalisasi.

Agama harus menjadi dasar yang kuat dalam bertindak dan mengambil sikap dalam menghadapi permasalahan yang sangat kompleks di era globalisasi ini. Sehingga penanaman nilai-nilai Islam dalam pembelajaran IPS harus dijadikan prioritas. Selain penanaman nilai-nilai Islam, yang perlu dilakukan dalam pembelajaran adalah mengkaitkan materi IPS bermuatan Islam. Serta memberikan 
contoh konkrit di lingkungan masyarakat yang bernilai positif, sehingga dapat diterapkan dalam kehidupan seharihari. Dengan demikian, materi IPS akan lebih bermakna, karena tidak hanya untuk kepentingan dunia tetapi juga kepentingan akhirat.

Berdasarkan uraian di atas, maka judul dalam penelitian ini adalah "Analisis Nilai-Nilai Karakter Islam dalam Pembelajaran IPS di MTs Mazro'illah Lubuklinggau."

Adapun penelitian yang dianggap relevan dengan penelitian ini, diantaranya adalah penelitian yang dilakukan oleh:

1. Rahmawati (2017) dengan judul "Pengintegrasian NilaiNilai dalam Pembelajaran IPS." Hasil kajian tersebut menyimpulkan bahwa: Melalui integrasi nilai-nilai dalam pendidikan IPS akan memberikan bekal kepada siswa dalam mengembangkan diri melalui berbagai keterampilan sosial dalam kehidupannya. Pendidikan IPS membekali siswa tentang pengetahuan, keterampilan, sikap, dan nilai, sehingga dapat membentuk citra diri siswa menjadi manusia yang memiliki jati diri yang mampu hidup di tengah masyarakat dengan damai, dan dapat memberikan manfaat kepada orang lain.

2. Muzianah (2017) "Upaya Guru Dalam Menginternalisasikan Nilai-Nilai Pendidikan Agama Islam Bagi Pembentukan Akhlakul Karimah di SDIT AsSunnah Kota Cirebon." Hasil penelitian ini menyimpulkan bahwa pendidikan akhlakul karimah merupakan proses penghayatan pada suatu falsafah secara mendalam melalui interaksi dua arah tanpa adanya pemaksaan anak didik melakukan segala sesuatu yang dilakukannya diyakini benar tidak menyimpang dari norma agama dan norma di masyarakat cukup berhasil dengan baik. Faktor-faktor yang mempengaruhinya yaitu faktor eksternal dan faktor internal. Keberhasilan aspek kognitif, afektif dan psikomotor mencapai nilai optimal dengan rata-rata di atas 75 dari setiap aspeknya.

3. Bermi (2017) dengan judul "Internalisasi Nilai-Nilai Agama Melalui Penciptaan Suasana Keagamaan di Lingkungan MI Muhammadiyah Tempurrejo Ngawi." Artikel ini menyimpulkan bahwa: Strategi penciptaan suasana keagamaan di lingkungan Madrasah Ibtidaiyah Muhammadiyah Tempurrejo antara lain: (1) Peningkatan kualitas keagamaan pegawai, baik guru maupun karyawan, melalui pembinaan-pembinaan, dan kegiatankegiatan keagamaan baik yang bersifat rutin maupun insidentil. (2) Pemberian peran kepada para guru dan karyawan agar mereka berpesan aktif dalam upaya penciptaan suasana keagamaan di lingkungan madrasah. (3) Penyempurnaan sarana prasarana yang terkait erat dengan penciptaan suasana keagamaan di lingkungan madrasah Wujud suasana keagamaan di lingkungan Madrasah Ibtidaiyah Muhammadiyah dapat dipilah dalam tiga wujud: (1) Fisik, yaitu meliputi keseluruhan bangunan fisik yang diciptakan untuk mendukung terciptanya suasana keagamaan di lingkungan madrasah.
Adapun wujud fisik suasana keagamaan di lingkungan madrasah antara lain: mushala sebagai pusat kegiatan ibadah yaumiyah, perpustakaan yang dilengkapi dengan buku-buku bacaan keislaman, tulisan-tulisan seperti kata hikmah dan kaligrafi, dan seperangkat aturan/tata tertib serta terciptanya suasana lingkungan yang bersih tertib, aman dan nyaman. (2) Kegiatan, yaitu keseluruhan kegiatan keagamaan yang diselenggarakan di madrasah. Adapun kegiatan-kegiatan sebagai wujud suasana keagamaan di lingkungan madrasah adalah: tartil AlQuran, shalat Jum'at berjama'ah, Jum'at bersih, pondok ramadhan, Peringatan Hari Besar Islam. (3) Sikap dan perilaku, yaitu keseluruhan sikap dan perilaku yang ditampilkan oleh para guru, karyawan, siswa di lingkungan madrasah, seperti: tegur sapa islami, saling bantu membatu, tenggang rasa, saling mengunjungi, saling menghormati, dan disiplin.

4. Isbandiyah (2017) dengan judul "Upaya Menyiapkan Generasi Emas Melalui Penanaman Nilai-Nilai Karakter dalam Pembelajaran Sejarah". Artikel ini menyimpulkan bahwa penanaman nilai-nilai karakter dapat dilakukan dengan cara mengintegrasikannya ke dalam setiap proses pembelajaran yang dilakukan oleh peserta didik. Selain itu juga dapat menggunkan pendekatan, metode, strategi, dan teknik pembelajaran nilai yang efektif untuk menamakan nilai-nilai karakter.

5. Supriana dan Rahmat Sugiharto (2017) dengan judul "Pembentukan Nilai-Nilai Karakter Islami Siswa Melalui Metode Pembiasaan (Studi Kasus di Madrasah Tsanawiyah Bandung Jawa Barat)". Jurnal Educan. Hasil temuan penelitian yaitu bahwa bentuk pembiasaan dalam pembentukan karakter Islami siswa di MTs Terpadu Ar-Roudloh Cileunyi Bandung adalah ada empat: (1) pembiasaan dalam akhlaq meliputi salam senyum sapa, hidup bersih, berdisiplin, dan gemar membaca buku; (2) pembiasaan dalam ibadah meliputi shalat Dhuha, Zuhur, dan Jum'at, membaca doa harian, puasa senin kamis dan membaca al-Qur'an; (3) pembiasaan dalam kegiatan tahunan meliputi peningkatan imtaq dan dakwah islamiyah, pembinaan kehidupan berbangsa dan bernegara, pembinaan karakter dan akhlak mulia, keorganisasian, kepemimpinan, dan pelatihan serta apresiasi seni budaya dan olahraga.

Berdasarkan artikel hasil penelitian relevan di atas, maka terdapat beberapa kesamaan dengan penelitian ini yaitu tentang nilai-nilai karakter dalam pembelajaran. Namun, yang mmbedakannya adalah lokasi dan waktu penelitian, serta subjek penelitiannya, di mana kajian dalam penelitian ini lebih memfokuskan atau terbatas pada analisis nilai-nilai karakter Islam yang tertanam dalam diri peserta didik dalam pembelajaran IPS di MTs, khususnya pada siswa kelas IX, sedangkan penelitian relvan di atas lebih menekankan pada upaya internalisasi/penanaman maupun integrasi dalam proses pembelajaran. 


\section{METODE PENELITIAN}

Metode penelitian yang digunakan dalam penelitian ini yaitu metode penelitian kualitatif dengan pendekatan deskriptif. Pendekatan deskriptif yang dimaksud dalam penelitian ini yaitu suatu prosedur penelitian yang berusaha untuk menggambarkan objek atau subjek penelitian baik itu berupa angka-angka ataupun kata-kata.

Penelitian ini dilaksanakan di MTs Mazro'illah Lubuklinggau. Pemilihan lokasi ini berdasarkan pertimbangan bahwa: (1) MTs Mazro'illah merupakan salah satu lembaga pendidikan di Lubuklinggau yang berbasis agama Islam, sehingga relevan dengan tujuan penelitian yaitu tentang internalisasi nilai-nilai Islam dalam pembelajaran; (2) salah satu indikator visi MTs Mazro'illah adalah diharapkan seluruh pencapai mutu dan prestasi selalu disertai dengan pencerminan diri setiap personal madrasah maupun output dan outcome madrasah yang memiliki akhlak mulia berdasarkan nilai-nilai Islami; dan (3) jarak lokasi penelitian tidak terlalu jauh, sehingga diharapkan dapat mempermudah peneliti dalam proses pengambilan data secara maksimal. Sedangkan waktu penelitian ini akan dilaksanakan pada semester ganjil tahun ajaran 2019-2020.

Subjek dalam penelitian ini adalah siswa kelas XI yang berjumlah 49 siswa. Pemilihan subjek dalam penelitian ini didasarkan pada pertimbangan bahwa siswa kelas XI cukup lama mendapatkan pendidikan nilai di sekolah dan di pondok pesantren, sehingga dapat melihat nilai-nilai apa saja yang telah tertanam dengan baik dalam diri siswa, dan siap memberikan informasi yang sebenarnya. Sedangkan objek yang akan dijadikan sasaran dalam penelitian ini nilai-nilai karakter Islam.

Adapun tahapan dalam penelitian ini mencakup tiga tahap: (1) tahap persiapan lapangan; (2) tahap penelitian lapangan; dan (3) tahap analisis data dan pelaporan penelitian.

Untuk mendapatkan data, peneliti menggunakan teknik koesioner. oesioner dibuat dengan 2 (dua) alternatif jawaban, yaitu "Ya" dan "Tidak". Untuk jawaban "Ya" diberi skor 1 (satu) dan jawaban "Tidak" diberi skor 0 (nol). Data yang diperoleh dari hasil koesioner kemudian dianalisis dengan menggunakan rumus persentase sebagai berikut.

$$
\text { Persentase }=\frac{\text { Skor yang Diperoleh }}{\text { Skor Total }} \times 100 \%
$$

Hasil dari perhitungan persentase kemudian diinterpretasikan yaitu jika rentang persentase yang diperoleh adalah lebih dari atau sama dengan $\geq 76 \%$, maka kualitasnya dinyatakan baik, dan jika rentang persentase yang diperoleh antara $56 \%-75 \%$, maka dinyatakan cukup, serta apabila di bawah dari atau sama dengan $\leq 55 \%$, maka kualitasnya dinyatakan rendah atau kurang.

\section{HASIL DAN PEMBAHASAN}

Hasil penelitian yang dilakukan dengan koesioner tentang nilai-nilai karakter Islam kepada kelas IX sebanyak 49 siswa, kemudian dilakukan analisis/penghitungan skor tiap subjek penelitian. Dalam penarikan simpulan suatu subjek untuk menentukan kecenderungan suatu nilai karakter Islam, penelitian ini menentukan 3 kelompok nilai yaitu: (1) nilai aqidah yang terdiri dari nilai religius, tanggungjawab, toleransi, dan jujur; (2) nilai ibadah yang terdiri dari menghargai prestasi, peduli sosial, peduli lingkungan, gemar membaca, rasa ingin tahu, mandiri, dan kerja keras/ketekunan; serta (3) nilai akhlak yang terdiri dari disiplin, bersahabat/komunikatif, dan demokratis. Untuk lebih jelasnya, di bawah ini akan dideskripsikan masing-masing nilai-nilai karakter Islam sebagai berikut.

\section{A. Nilai Aqidah}

Nilai aqidah terdiri dari 4 (empat) nilai karakter Islam, yaitu nilai religius, tanggungjawab, toleransi, dan jujur, dan masing-masing nilai karakter tersebut memiliki indikator.

Berdasarkan analisis data nilai aqidah pada siswa kelas IX $_{1}$ diperoleh bahwa ada 10 siswa yang $100 \%$ menjawab dengan tepat seluruh indikator pada masingmasing nilai. Artinya nilai religius, tanggungjawab, toleransi, dan jujur telah tertanam dengan baik dalam diri sepuluh siswa tersebut. Sementara pada siswa yang lain empat nilai tersebut belum sepenuhnya tertanam. Apabila disesuaikan dengan pendapat Arikunto (2006) yang menyatakan bahwa jika rentang persentase yang diperoleh adalah lebih dari atau sama dengan $\geq 76 \%$, maka kualitasnya dinyatakan baik, dan jika rentang persentase yang diperoleh antara 56\%-75\%, maka dinyatakan cukup, serta apabila di bawah dari atau sama dengan $\leq 55 \%$, maka kualitasnya dinyatakan rendah atau kurang. Maka terdapat 19 siswa yang memiliki nilai aqidah yang baik, dan terdapat 3 (tiga) siswa yang nilai aqidahnya masih dalam kategori cukup. Walau demikian, 19 siswa tersebut masih harus terus dibina, karena hanya 10 siswa yang $100 \%$ memiliki nilai aqidah, selebihnya harus mendapat pendidikan nilai yang serius, terutama 3 (tiga) siswa yang nilai aqidahnya masih cukup.

Selanjutnya hasil analisis nilai aqidah pada kelas $\mathrm{IX}_{2}$ diperoleh nilai bahwa semua siswa kelas IX $_{2}$ memiliki nilai aqidah yang baik. Hal ini dilihat dari nilai persentase yang diperoleh dari hasil pengisian koesioner dengan nilai ratarata persentase sebesar 94\%. Selain itu, dilihat dari pendapat Arikunto (2006) yang menyatakan bahwa jika rentang persentase yang diperoleh adalah lebih dari atau sama dengan $\geq 76 \%$, maka nilai aqidah yang diperoleh dinyatakan baik. Jadi, secara keseluruhan nilai religius, tanggungjawab, toleransi, dan jujur telah tertanam dengan baik dalam diri semua siswa kelas $\mathrm{IX}_{2}$. Namun, dilihat dari indikator nilai yang dijawab oleh masing-masing siswa, maka dari semua siswa hanya 7 (tujuh) siswa yang $100 \%$ nilai-nilai tersebut tertanam dalam dirinya. Sementara 8 
(delapan) siswa yang lain hanya 95,83\%, 7 (tujuh) siswa $91,67 \%, 2$ (dua) siswa 87,5\%, 2 (dua) siswa 83,33\%, dan 1 (satu) siswa 79,17\%. Artinya masih ada separuh lebih siswa kelas $\mathrm{IX}_{2}$ yang nilai aqidahnya perlu mendapat perhatian dan terus dibina serta dididik lebih lanjut.

Berikut ini merupakan hasil analisis dari penggabungan nilai aqidah dari kelas $\mathrm{IX}_{1}$ dan kelas $\mathrm{IX}_{2}$.

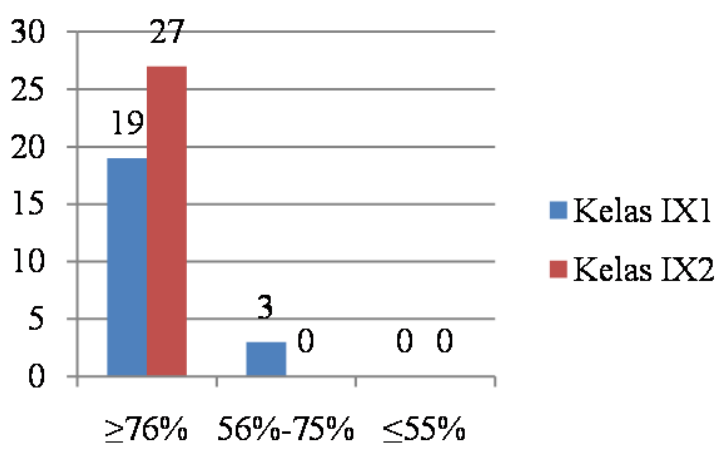

Gambar 1.Diagram Nilai Aqidah Kelas IX $_{1}$ dan Kelas IX 2

Berdasakan diagram di atas, terlihat bahwa persentase nilai aqidah yang mendapatkan $\geq 76 \%$ dengan kategori "baik" sebanyak 38 siswa, yang terdiri dari 19 siswa kelas IX $_{1}$ dan 27 siswa kelas IX $_{2}$. Kemudian persentase nilai aqidah yang mendapatkan antara $56 \%-75 \%$ dengan kategori "cukup" sebanyak 3 (tiga) siswa dari kelas $\mathrm{IX}_{1}$. Sedangkan untuk persentase nilai aqidah yang mendapatkan $\leq 55 \%$ dengan kategori "kurang" tidak ada.

\section{B. Nilai Ibadah}

Nilai ibadah dalam penelitian ini terdiri dari 7 (tujuh) nilai karakter Islam, yaitu menghargai prestasi, peduli sosial, peduli lingkungan, gemar membaca, rasa ingin tahu, mandiri, dan kerja keras/ketekunan. Seperti pada nilai sebelumnya, hasil penelitian untuk nilai ibadah ini juga akan dideskripsikan ke dalam dua kelompok, yaitu hasil penelitian pada kelas $\mathrm{IX}_{1}$ dan hasil penelitian pada kelas $\mathrm{IX}_{2}$.

Hasil analisis nilai ibadah pada kelas IX $_{1}$ dapat peneliti jelaskan bahwa nilai ibadah yang $100 \%$ tertanam hanya pada 2 (dua) siswa saja, sementara ada 19 siswa dengan kategori baik, namun masih di bawah $100 \%$, yaitu memperoleh nilai rata-rata persentase sebesar $86,84 \%$, dan ada 1 (satu) siswa yang memiliki nilai ibadah dengan kategori rendah atau kurang, yaitu mendapat nilai persentase sebesar 47,5\%. Hal ini menandakan bahwa secara keseluruhan dalam belajar mata pelajaran IPS siswa kelas $\mathrm{IX}_{1}$ masih harus ada tindak lanjut dalam menginternalisasikan nilai-nilai karakter Islam, khusus pada nilai Ibadah bagian kemandirian, gemar membaca, rasa ingin tahu, peduli lingkungan, dan peduli sosial. Karena secara berurutan nilai-nilai tersebut yang kurang dalam diri siswa.
Selanjutnya hasil analisis ibadah pada kelas $\mathrm{IX}_{2}$ dapat dilihat bahwa ada 7 (tujuh) siswa yang $100 \%$ nilai ibadah tertanam dalam dirinya, dan 19 siswa juga tertanam nilai ibadah dalam dirinya dalam kategori baik namun belum $100 \%$, yang secara rinci nilai persentasenya yaitu: 1 (satu) siswa 97,5\%, 4 (empat) siswa 95\%, 2 (dua) siswa 92,5\%, 4 (empat) siswa 90\%, 1 (satu) siswa 97,5\%, 2 (dua) siswa $82,5 \%, 2$ (dua) siswa 77,5\%, 1 (satu) siswa 75\%, 1 (satu) siswa $72,5 \%$, dan 1 (satu) siswa 62,5\%. Sementara yang 1 (satu) siswa nilai ibadahnya dalam kategori rendah atau kurang dengan nilai persentase sebesar $50 \%$. Dilihat dari total indikator yang dijawab dengan tepat, yang sangat perlu ditindaklanjuti adalah menanamkan nilai kemandirian, rasa ingin tahu, dan gemar membaca, sementara nilai yang mendominasi adalah menghargai prestasi, peduli sosial, peduli lingkungan, dan kerja keras/ketekunan. Dengan demikian, internalisasi nilai ibadah pada kelas IX $_{2}$ masih harus terus dikembangkan, sehingga menjadi lebih baik.

Berikut ini merupakan hasil analisis dari penggabungan nilai ibadah dari kelas IX $_{1}$ dan kelas IX 2 .

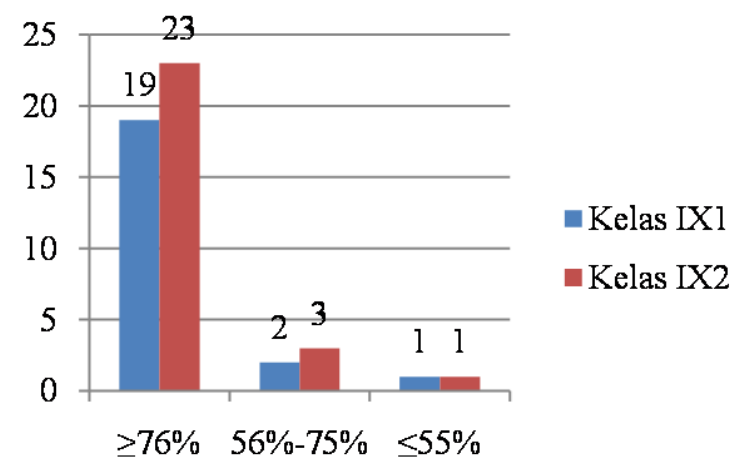

Gambar 2. Diagram Nilai Ibadah Kelas IX $_{1}$ dan Kelas IX

Berdasakan diagram di atas, terlihat bahwa persentase nilai ibadah yang mendapatkan $\geq 76 \%$ dengan kategori "baik" sebanyak 42 siswa, yang terdiri dari 19 siswa kelas $\mathrm{IX}_{1}$ dan 23 siswa kelas $\mathrm{IX}_{2}$. Kemudian persentase nilai ibadah yang mendapatkan antara $56 \%-75 \%$ dengan kategori "cukup" sebanyak 5, yang terdiri dari 2 (dua) siswa dari kelas $\mathrm{IX}_{1}$ dan 1 (satu) siswa kelas $\mathrm{IX}_{2}$ Sedangkan untuk persentase nilai ibadah yang mendapatkan $\leq 55 \%$ dengan kategori "kurang" sebanyak 2 (dua) siswa, yaitu 1 (satu) siswa dari kelas IX $_{1}$ dan 1 (satu) siswa dari kelas $\mathrm{IX}_{2}$.

\section{Nilai Akhlak}

Nilai akhlak terdiri dari 3 (tiga) nilai karakter Islam, yaitu disiplin, bersahabat/komunikatif, dan demokratis. Hasil penelitian untuk nilai akhlak ini juga akan dideskripsikan ke dalam dua kelompok, yaitu hasil penelitian pada kelas $\mathrm{IX}_{1}$ dan hasil penelitian pada kelas $\mathrm{IX}_{2}$. 
Hasil analisis nilai akhlak pada kelas IX $_{1}$ dapat dijelaskan bahwa terdapat 12 siswa yang $100 \%$ memiliki nilai akhlak yang baik, sementara yang 10 siswa juga memiliki nilai akhlak yang baik namun belum $100 \%$, dengan rincian yaitu 3 (tiga) siswa mendapat nilai persentase sebesar 94,74\%, 3 (tiga) siswa mendapat nilai persentase sebesar $89,47 \%, 2$ (dua) siswa mendapat nilai persentase sebesar $84,21 \%, 1$ (satu) siswa mendapat nilai persentase sebesar $73,68 \%$, dan 1 (satu) siswa mendapat nilai persentase sebesar $63,16 \%$. Dari jumlah indikator yang terjawab dengan tepat, nilai akhlak yang tertanam dengan baik didominasi nilai disiplin dan diikuti nilai bersahabat/komunikatif dan nilai demokratis. Dengan demikian, nilai-nilai akhlak yang telah tertanam dalam diri siswa kelas $\mathrm{IX}_{1}$ termasuk dalam kategori bagus, karena lebih dari separuh siswa $100 \%$ menjawab seluruh indikator dengan tepat.

Selanjutnya hasil analisis nilai akhlak pada kelas $\mathrm{IX}_{2}$ ditemukan sebanyak 20 siswa telah tertanam nilai akhlak dalam dirinya dengan nilai persentase $100 \%$, sementara 7 siswa yang lain masih di bawah $100 \%$, dengan rincian 3 (tiga) siswa nilai akhlaknya 94,74\%, 2 (dua) siswa nilai akhlaknya 89,47\%, dan 2 (dua) siswa nilai akhlaknya sebesar $84,21 \%$. Dengan demikian, nilai akhlak yang terdiri dari nilai disiplin, bersahabat/komunikatif, dan demokratis telah tertanam dengan baik dalam diri siswa kelas $\mathrm{IX}_{2}$ yang didominasi oleh nilai disiplin, selanjutnya nilai bersahabat/ komunikatif, dan berikutnya nilai demokratis.

Berikut ini merupakan hasil analisis dari penggabungan nilai akhlak dari kelas $\mathrm{IX}_{1}$ dan kelas $\mathrm{IX}_{2}$.

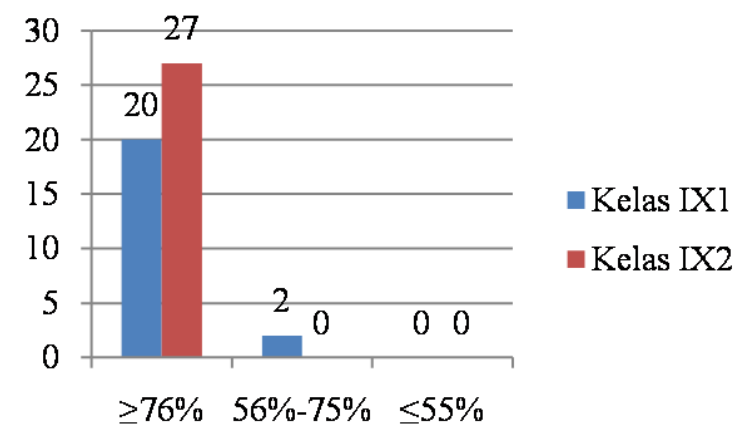

Gambar 3. Diagram Nilai Akhlak Kelas IX $_{1}$ dan Kelas IX ${ }_{2}$

Berdasakan diagram di atas, terlihat bahwa persentase nilai akhlak yang mendapatkan $\geq 76 \%$ dengan kategori "baik" sebanyak 47 siswa, yang terdiri dari 20 siswa kelas IX $_{1}$ dan 27 siswa kelas IX $_{2}$. Kemudian persentase nilai akhlak yang mendapatkan antara $56 \%-75 \%$ dengan kategori "cukup" sebanyak 2 (dua) siswa dari kelas IX $_{1}$. Sedangkan untuk persentase nilai akhlak yang mendapatkan $\leq 55 \%$ dengan kategori "kurang" tidak ada.

Berdasarkan seluruh analisis di atas, maka secara keseluruhan antara nilai aqidah, nilai ibadah, dan nilai akhlak lebih didominasi oleh nilai akhlak, kemudian nilai aqidah, dan selanjutnya nilai ibadah. Untuk lebih jelasnya, perolehan nilai persentase dari ketiga kelompok nilai akhlak, nilai aqidah, dan nilai ibadah, dapat dilihat pada diagram di bawah ini.

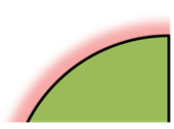

95,7 91,67 $\square$ Nilai A $\square$ Nilai Ib $\square$ Nilai A

87,5

Gambar 4. Diagram Persentase Nilai-Nilai Karakter Islam

Pada diagram di atas menunjukkan bahwa secara keseluruhan nilai-nilai karakter Islam sudah tertanam baik di dalam diri siswa, hal ini dapat dilihat dari hasil perolehan persentase untuk masing-masing nilai-nilai karakter Islam yang dikelompokkan menjadi tiga kategori, yaitu (1) nilai aqidah dengan jumlah persentase sebesar 91,67\%; (2) nilai ibadah dengan jumlah persentase yang diperoleh sebesar 87,5\%; dan (3) nilai akhlak dengan jumlah persentase yang diperoleh sebesar 95,7\%. Dari ketiga kategori nilai-nilai karakter Islam tersebut, maka nilai karakter yang paling tertanam adalah nilai akhlak, kemudian disusul dengan nilai aqidah, dan terakhir adalah nilai ibadah.

\section{KESIMPULAN}

Berdasarkan hasil penelitian dan pembahasan maka dapat disimpulkan bahwasannya nilai-nilai karakter Islam peserta didik dalam pembelajaran IPS secara keseluruhan tertanam dengan baik. Nilai-nilai karakter Islam yang tertanam dengan baik secara berurutan yaitu nilai akhlak, nilai aqidah, dan nilai ibadah.

\section{DAFTAR PUSTAKA}

Arikunto, Suharsimi. (2006). Prosedur Penelitian Suatu Pendekatan Praktik. Jakarta: Rineka Cipta.

Bermi, Wibawati. (2017). Internalisasi Nilai-Nilai Agama Melalui Penciptaan Suasana Keagamaan di Lingkungan MI Muhammadiyah Tempurrejo Ngawi. Jurnal Al-Lubab, ISSN: 2502-1850, Volume 3, Nomor 2, November 2017, 39-55

Gunawan, Heri. (2012). Pendidikan Karakter: Konsep dan Implementasi. Bandung: Alfabeta.

Gunawan, Rudy. (2016). Pendidikan IPS: Filosofi, Konsep, dan Aplikasi. Bandung: Alfabeta.

Isbandiyah. (2017). Upaya Menyiapkan Generasi Emas Melalui Penanaman Nilai-Nilai Karakter dalam Pembelajaran Sejarah. Jurnal Ilmiah Pena (Sains dan 
Ilmu Pendidikan). Vol. 12 No.1, November 2017, 4351.

Muzianah, Siti. (2017). Upaya Guru dalam Menginternalisasikan Nilai-Nilai Pendidikan Agama Islam Bagi Pembentukan Akhlakul Karimah di SDIT As Sunnah Kota Cirebon. OASIS: Jurnal Ilmiah Kajian Islam. Vol (2) No (1), Agustus 2017, 60-78.

Rahmawati, Isna. (2017). Pengintegrasian Nilai-Nilai dalam Pembelajaran IPS. Jurnal Magistra, No. 100 Th. XXIX Juni 2017, 1-10.

Supiana dan Rahmat Sugiharto. (2017). dengan judul Pembentukan Nilai-Nilai Karakter Islami Siswa Melalui Metode Pembiasaan (Studi Kasus di Madrasah Tsanawiyah Bandung Jawa Barat). Jurnal Educan. Vol. 01, No. 01, Februari 2017, 89-109. 